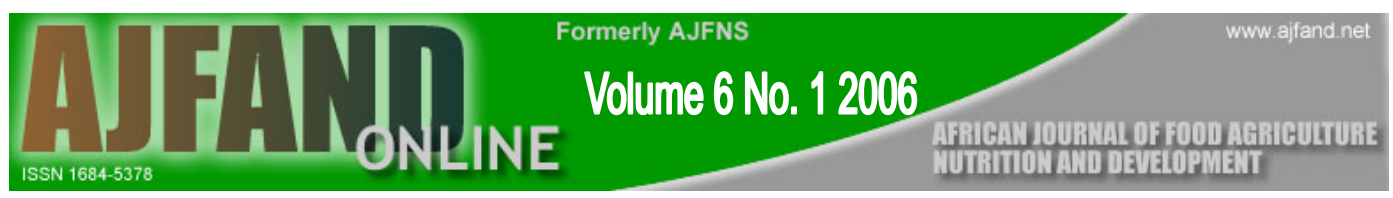

\title{
EFFECTS OF BLANCHING AND SOAKING ON SOME PHYSICAL CHARACTERISTICS OF GRASS PEA (LATHYRUS SATIVUS)
}

\author{
Urga $\mathrm{K}^{1^{*}}$, Fufa $\mathrm{H}^{2}$, Biratu $\mathrm{E}^{2}$, Gebretsadik $\mathrm{M}^{2}$
}

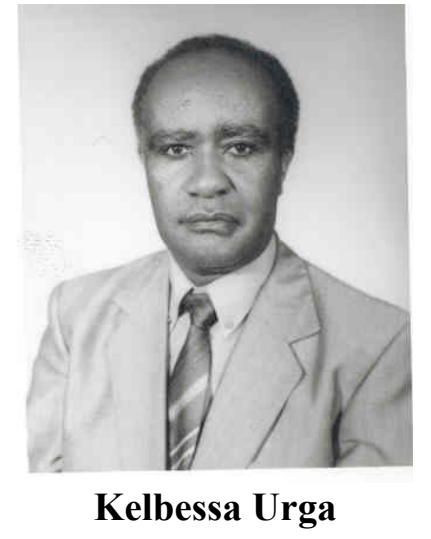

*Corresponding author email: $\underline{\text { ddr@ethionet.et }}$

${ }^{1}$ Department of drug Research

${ }^{2}$ Department of Food Science and Nutrition

Ethiopian Health and Nutrition Research Institute

P.O.Box 1242 or 5654, Addis Ababa, Ethiopia

E-mail: ddr@ethionet.et or ehnri@ethionet.et

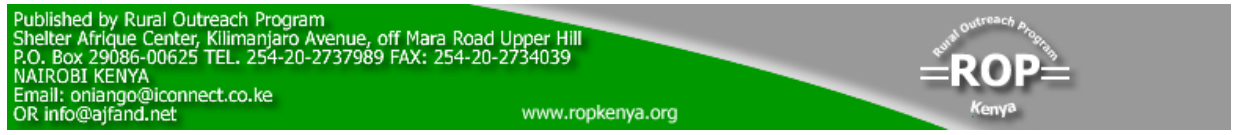




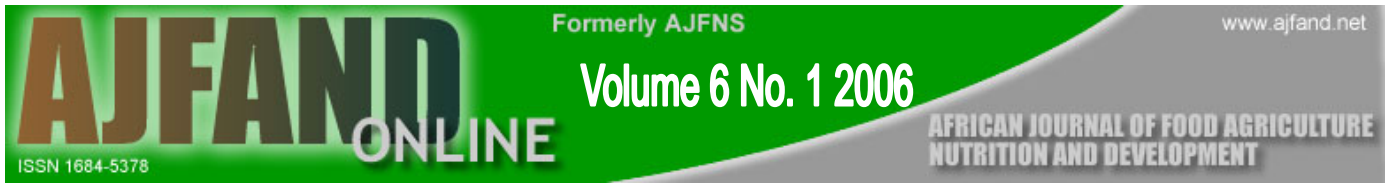

\section{ABSTRACT}

Lathyrus sativus, containing a lathyritic principle, called ß-ODAP (ß-N-Oxalyl-L$\alpha$, B-diaminopropionic acid), is widely grown and consumed in Ethiopia. It is a hardy crop grown under various agro-ecological situations. The major drawback in the use of the legume is the fact that the seeds, in common with other legumes, are not easily rehydrated, are difficult to cook, the seed coat is difficult to remove and long cooking time is required by traditional processing methods for tenderization. In this study, the effect of processing methods like blanching, soaking and cooking on water absorption, leached solids, swelling power, cooking time and sensory qualities of grass pea seeds were investigated. The soaking solutions used were mixed with salt solution, wood ash solution and double distilled de-ionized water. Blanching significantly $(p<0.05)$ increased total water absorbed, swelling power, leached solids and reduced cooking time compared to unbalanced seeds. Soaking blanched seeds in salt or wood ash solution was noted to be most effective in promoting seed softening during cooking, compared to double distilled water. Blanched grass pea seeds soaked for 12 hours in the three soaking solutions caused reduction of $60 \%, 73 \%$ and $68 \%$, respectively, in cooking time. In contrast, unblanched grass pea seeds soaked for 12 hours in the three soaking solutions caused reduction of $30 \%, 46 \%$ and $40 \%$, respectively, in cooking time. Water absorption, swelling power and leached solids values were negatively correlated $(p<0.05)$ with the cooking time. The study results indicated that blanching and hydration of grass pea seeds improved the sensory characteristics of cooked seeds, significantly reduced the cooking time and increased the weight and texture of the cooked seeds. Application of blanching preceded by soaking at village level as an integral part of traditional methods of processing grass pea seeds, thus offers the dual advantage of saving of valuable fuels by shortening cooking time, as well as rendering the seeds more acceptable to consumers. In the absence of salt, wood ash suspension treatment may be a satisfactory alternative in the production of quick-cooking grass pea seeds.

Key words: blanching, cooking, Lathyrus sativus, soaking 


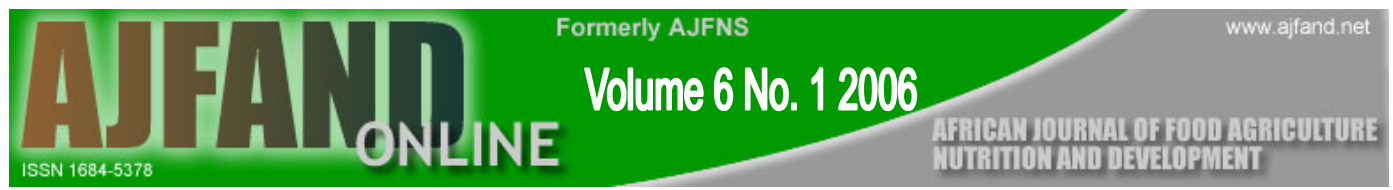

\author{
EFFETS DU BLANCHISSEMENT ET DU TREMPAGE (immersion) SUR \\ CERTAINES CARACTÉRISTIQUES PHYSIQUES DE LA GESSE BLANCHE \\ (LATHYRUS SATIVUS)
}

RÉSUMÉ

Lathyrus sativus, qui contient un principe lathyritique appelé $ß-O D A P$ (ß-N-Oxalyl-L$\alpha$, ß-acide diaminopropionique), est largement cultivé et consommé en Ethiopie. C'est une culture résistante qui pousse dans différentes situations agro-écologiques. Le plus grand inconvénient de l'utilisation de cette légumineuse est le fait que les graines, en commun avec d'autres légumineuses, ne sont pas facilement réhydratées, sont difficiles à cuire, le tégument (l'enveloppe de la graine) est difficile à enlever et les méthodes de traitement traditionnelles exigent beaucoup de temps de cuisson pour que la graine devienne tendre. Dans la présente étude, l'effet des méthodes de traitement - telles que le blanchissement, le trempage et la cuisson - sur l'absorption de l'eau, des solides lessivés, le pouvoir de gonflement, le temps de cuisson et les qualités sensorielles des graines de la gesse blanche ont fait l'objet de recherche. Les solutions du trempage ont été des mélanges de solution de sel, de solution de cendre de bois et de l'eau désionisée doublement distillée. Le blanchissement a considérablement $(p<0,05)$ augmenté la quantité totale de l'eau absorbée, le pouvoir de gonflement et les solides lessivés, et il a réduit le temps de cuisson par rapport aux graines déséquilibrées. Il a été constaté que le trempage des graines dans du sel ou dans une solution de cendre de bois est le plus efficace pour promouvoir l'adoucissement des graines au cours de la cuisson, par rapport à l'eau doublement distillée. Les graines de gesse blanchies trempées pendant 12 heures dans trois solutions de conservation ont causé la réduction de $60 \%, 73 \%$ et $68 \%$, respectivement, du temps de cuisson. Par contre, les graines de gesse non blanchies trempées pendant 12 heures dans les trois solutions de conservation ont causé la réduction de $30 \%$, $46 \%$ et $40 \%$, respectivement, dans le temps de cuisson. Les valeurs de l'absorption de l'eau, du pouvoir de gonflement et des solides lessivés ont eu une corrélation négative $(p<0,05)$ avec le temps de cuisson. Les résultats de cette étude ont indiqué que le blanchissement et l'hydratation des graines de gesse ont amélioré les caractéristiques sensorielles des graines cuites, ont considérablement réduit le temps de cuisson et augmenté le poids et la couleur des graines cuites. L'application du blanchissement précédé par le trempage, au niveau du village en tant que partie intégrante des méthodes traditionnelles de traitement des graines de gesse, offre ainsi le double avantage d'économiser les combustibles si chers en raccourcissant le temps de cuisson et en rendant les graines plus acceptables aux consommateurs. En l'absence du sel, le traitement de la suspension de la cendre de bois peut être une alternative satisfaisante dans la production de graines de gesse rapides à cuire.

Mots-clés: blanchissement, cuisson, Lathyrus sativus, trempage.

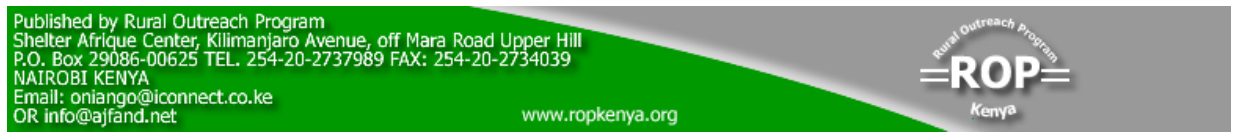




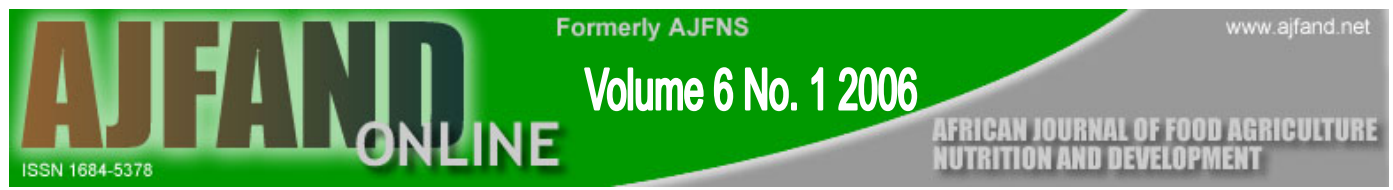

\section{INTRODUCTION}

Grain legumes are important crops in Ethiopia in many ways. They play an important role in providing the bulk of protein requirement for Ethiopians and constitute an integral part of the staple diet. Grass pea (Lathyrus sativus) is one of the important grain legume crops. The legume has unique adaptation to extreme harsh conditions of dry lands. It is grown on heavy black clay soils with poor drainage where there is no possibility for production of any other alternative pulse. Despite its tolerance to drought, grass pea is not affected by excessive rainfall and can be grown on land, subject to flooding [1]. Production of Lathyrus sativus ranks third among legumes. The major growing areas are mainly concentrated in the North West, Central and Eastern highlands [2].

Grass pea is an important food item in Ethiopia and is prepared in a wide variety of dishes. Most often the legume is used as shiro wott (the traditional Ethiopian spiced dish), kikh wott (decorticated split cotyledon prepared into a spiced soup-like dish), nifro (boiled and salted whole seed), kolo (roasted whole seed), kitta (unleavened flat bread) and diffo dabbo (sourdough bread prepared by mixing one-third of grass pea flour with two-third of wheat flour). Both shiro and kikh wott are eaten with kitta, diffo dabbo or injera (pancake-like fermented thin bread prepared from cereals) [3]. Moreover, grass pea provides cheap and quality fodder. After harvesting, the dried straw and chaff are fed to farm animals.

In addition to the presence of the neurotoxin $\beta$-ODAP in grass pea seeds, the major drawback in the use of the legume is the fact that the seeds, in common with other legumes, are not easily rehydrated, they are difficult to cook, the seed coat is difficult to remove and long cooking time is required by traditional processing methods to tenderize the grain. Extended cooking time of the legume does not encourage its consumption - due to lack of convenience, fuel cost and nutritive value. Previous studies have reported that grass pea seeds require $270 \mathrm{~min}$ for cooking into tender and acceptable nifro [4]. A number of techniques have therefore, been utilized to render the dry grass pea seeds quick-cooking and sufficiently tender for human consumption. These include soaking of the seeds in different soaking solutions proceeded by cooking. Unlike other legumes, no comprehensive study has been reported on effects of pre-treatment methods on the cooking quality of grass pea seeds. This study reports the effects of some soaking solutions on water absorption, level of leached solids, swelling power, cooking time and sensory qualities of grass pea seeds. 


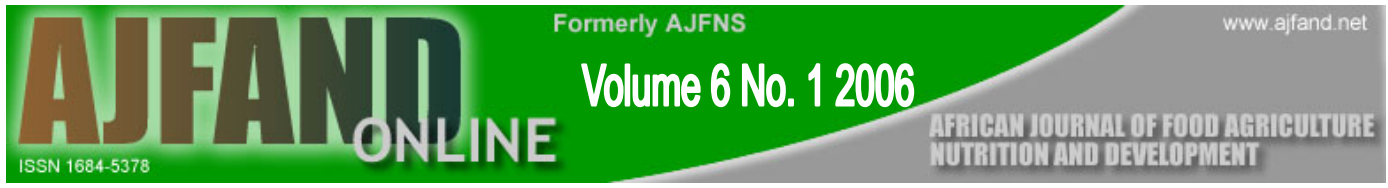

\section{MATERIALS AND METHODS}

Grass pea seeds: Seeds of a local variety were purchased within one month of harvest from farmers in Ambo, Western Ethiopia. Wood ash was also obtained from the farmers' homes. The seeds were visually inspected and any foreign material removed. The seeds were stored in sealed plastic bags at ambient temperature, and used within three months of harvest.

\section{Soaking solutions}

\section{a. Mixed salt solution}

$\begin{array}{ll}\text { Bicarbonate } & 1.5 \% \mathrm{w} / \mathrm{v} \\ \text { Soda ash } & 0.5 \% \mathrm{w} / \mathrm{v} \\ \text { Citric acid } & 0.75 \% \mathrm{w} / \mathrm{v}\end{array}$

$$
\mathrm{pH} 7.0 \pm 0.05
$$

\section{b. Wood ash solution}

$100 \mathrm{~g}$ sieved wood ash was dissolved in $1 \mathrm{~L}$ of de-ionized water and filtered through Whatman No.1 filter paper. Citric acid ( $3.5 \mathrm{~g})$ was added to the filtrate to adjust the $\mathrm{pH}$ to $7.0 \pm 0.05$.

\section{c. Water}

Double distilled deionized water

Blanching and soaking: Aliquots $(10 \mathrm{~g})$ of dry seeds were blanched in $50 \mathrm{ml}$ of boiling double distilled deionized water for 5 minutes. The blanched seeds were drained and then placed in $50 \mathrm{ml}$ of double distilled deionized water, salt or wood ash solution and left to soak at $23 \pm 2{ }^{\circ} \mathrm{C}$ for $12 \mathrm{~h}$. Triplicate samples of $5.0 \mathrm{~g}$ (weighed accurately) were also soaked without blanching in $25 \mathrm{ml}$ double distilled deionized water, salt or wood ash solution for $12 \mathrm{~h}$ and used as control.

Water absorption and swelling power: For water absorption measurement, soaked seeds were drained, rinsed with double distilled deionized water, blotted dry with paper towel, and weighed. Absorption measurements were done after $1 \mathrm{~h}, 3 \mathrm{~h}, 6 \mathrm{~h}, 9 \mathrm{~h}$, and $12 \mathrm{~h}$ soaking. The soaking solutions were evaporated and dried at $105 \pm 2{ }^{\circ} \mathrm{C}$ in a gravity convection oven to constant weight to determine lost solids. Water absorption for the cooked seeds was determined in a manner similar to that for soaked grass pea seeds. Water absorption and swelling power were calculated by the equations described by Plhak et al. [5].

$$
\mathrm{WA}=\frac{(\text { drained } w t)-(\text { initial dry } w t-S L)}{(\text { initial dry } w t-S L)} \times 100 \%
$$


$\mathrm{SP}=\frac{(\text { drained volume })-(\text { initial volume })}{(\text { initial dry wt }-\mathrm{SL})} \times 100 \%$

Where SL is the solids lost during soaking or cooking.

Cooking time: Blanched or unblanched (control) seeds soaked in water, salt or wood ash solution and drained were cooked in boiling double distilled deionized water (seed: water ratio, 1:4 w/v) until they were softened to uniform mass when pressed between two glass slides so that no hard material was found as described by Narasimha and Desikachar [6]. The time required to obtain such a consistently cooked product was recorded as the cooking time.

Sensory evaluation: Sensory properties such as color, mouth feel, flavor, taste, texture and general acceptability of pre-treated seeds were evaluated by 10 panel members. Since women are involved in preparation of grass pea food products, female panelists familiar with grass pea products were selected from the Institute. Freshly boiled samples were served for sensory evaluation. A hedonic scale of; $1=$ poor, $2=$ fair, 3 $=$ good and 4 = excellent, was used for color, mouth feel, flavour, taste and general acceptability attributes. Tenderness was determined subjectively by feeling between the fingers as done traditionally. Tenderness was scored on a 1 to 4 scale, with a rating for, 1 very hard seeds and 4, very soft seeds. The time required to achieve a rating of 4 (soft) was compared with the cooking time. Comparisons between treatments were analyzed for significant difference $(\mathrm{p}<0.05)$ by using one-way analysis of variance. Data were analyzed using the SPSS Statistical Package (version 10, SPSS Inc, Chicago, Il, USA).

\section{RESULTS}

Table 1 shows values of swelling power and leached solids for unblanched seeds. Values for water absorption of seeds soaked in the 3 soaking solutions were identical during the first hour of soaking which then varied according to both time of soaking and soaking solution (Figure 1). Water absorption values were comparable for seeds soaked for 6 or 12 hours in wood ash or salt solution. Un-blanched seeds soaked for 12 hours in both wood ash or salt solution exhibited equal swelling power and solids leached which are more than 2-fold the swelling power and leached solids of seeds soaked in water.

Water absorption of blanched seeds soaked for 12 hours in water increased by more than 3-fold whereas, the values increased slightly in the other soaking solutions (Figure 2). None of the soaked seeds however, attained water absorption value of $100 \%$ after 12 hours soaking in all the 3 solutions. The rate of increase in volume (swelling power) of the blanched seeds soaked for 12 hours in salt and wood ash solutions were comparable while seeds soaked in water for a similar length of time increased by more than 4-fold (Table 2). Values for swelling power and leached solids of blanched seeds soaked for 12 hours in salt and wood ash solutions were significantly higher than those 


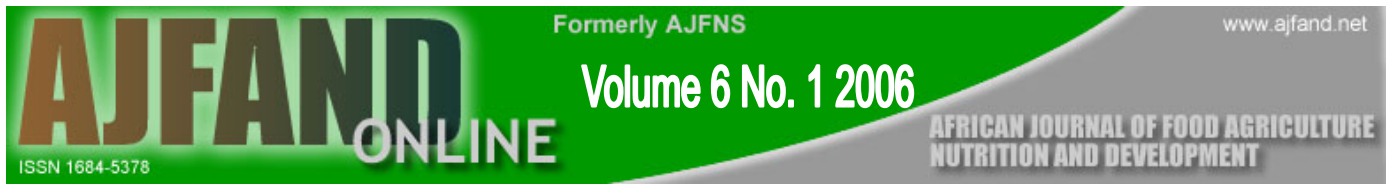

soaked in water. Water absorption, swelling power and leached solids values were significantly and positively correlated with the soaking time $(p<0.05)$.

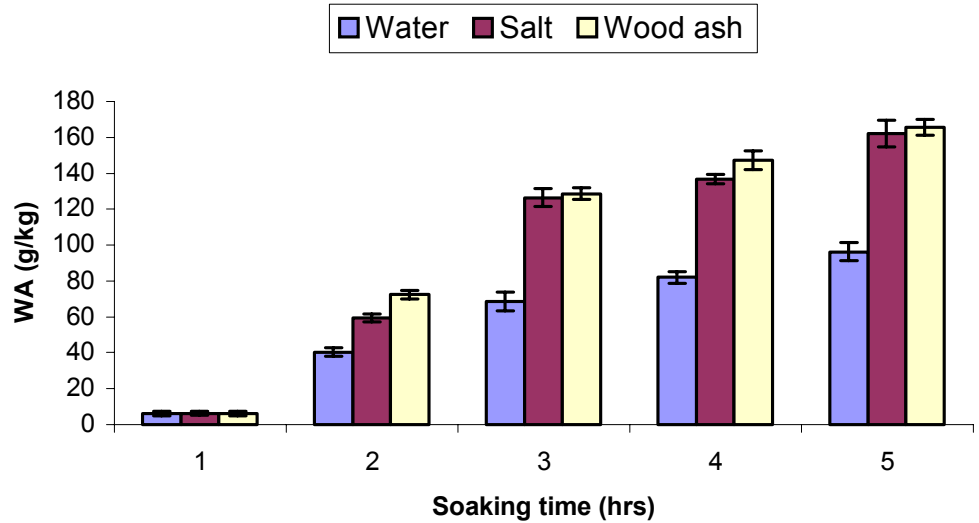

Figure 1. Water absorption (WA) of unblanched grass pea seeds. Data represents \pm of S.E.M five independent tests

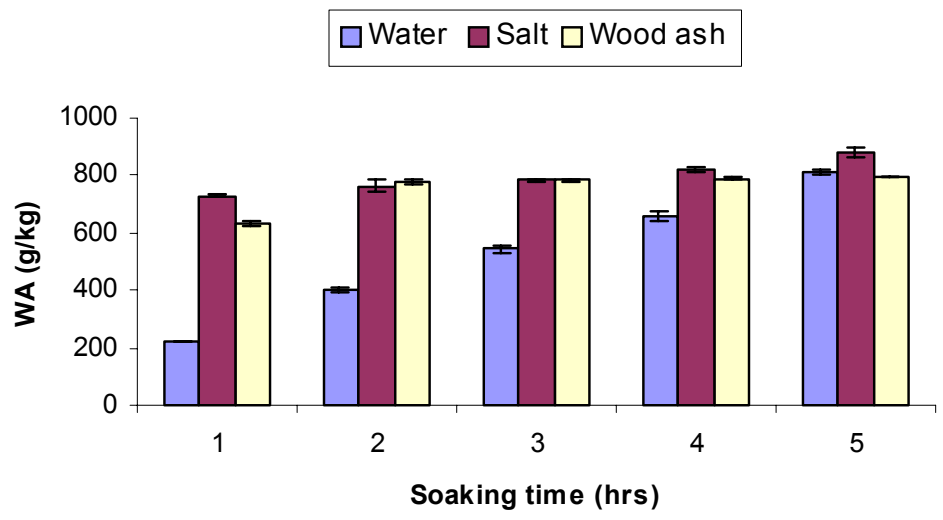

Figure 2. Water absorption (WA) of blanched grass pea seeds. Data represents \pm of S.E.M five independent tests

Table 3 indicates cooking characteristics of blanched and soaked seeds. When blanched seeds were soaked for 12 hours in water, salt and wood ash solution and then cooked to eating 'soft', water absorption increased by only $18 \%, 8 \%$ and $9 \%$, respectively. In

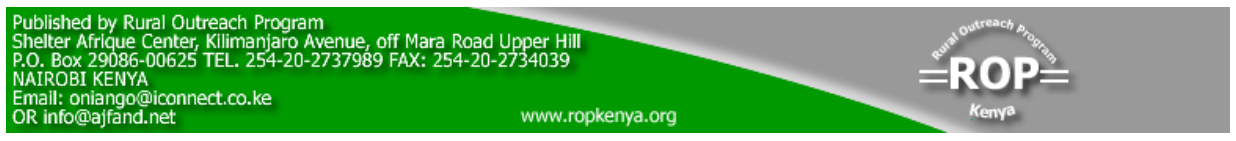


contrast, the swelling power of blanched grass peas soaked for 12 hours in water and cooked to 'eating soft' increased by $54 \%, 47 \%$ and $27 \%$, respectively. The levels of solids leached into the cooking water similarly increased by $17 \%, 23 \%, 30 \%$, respectively. Unblanched grass pea seeds soaked for 12 hours in the three soaking solutions caused reduction of $30 \%, 46 \%$ and $40 \%$, respectively, in cooking time (Figure 3). In contrast, blanched grass pea seeds soaked for 12 hours in the three soaking solutions caused reduction of $60 \%, 73 \%$ and $68 \%$, respectively, in cooking time (Figure 4). For blanched seeds variation in the degree of hydration expressed as the ratio of cooked weight to the dry weight is not significant over soaking time and soaking solution. However, blanched seeds soaked in water for 12 hours had a relatively lower degree of hydration than seeds soaked for a similar length of time in salt or wood ash solutions.

Test panel scores for blanched and unblanched grass pea seeds cooked after pretreatment in the three soak solutions are presented in Table 4. Results of the sensory evaluation indicated that unblanched seeds exhibited less overall acceptance scores compared to blanched seeds. The overall acceptance scores of blanched seeds soaked in salt solution were higher, compared to blanched seeds soaked in water and wood ash solution

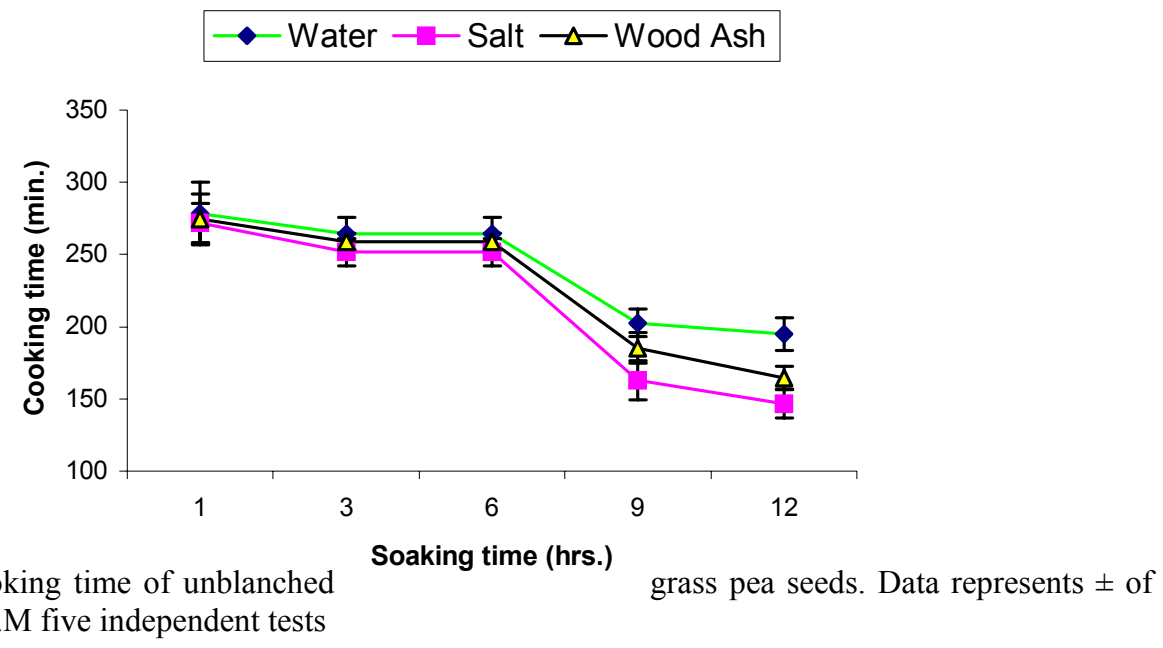

Figure 3 Cooking time of unblanched S.E.M five independent tests 
$\multimap-$ Water $\rightarrow-$ Wood Ash $\rightarrow-$ Salt

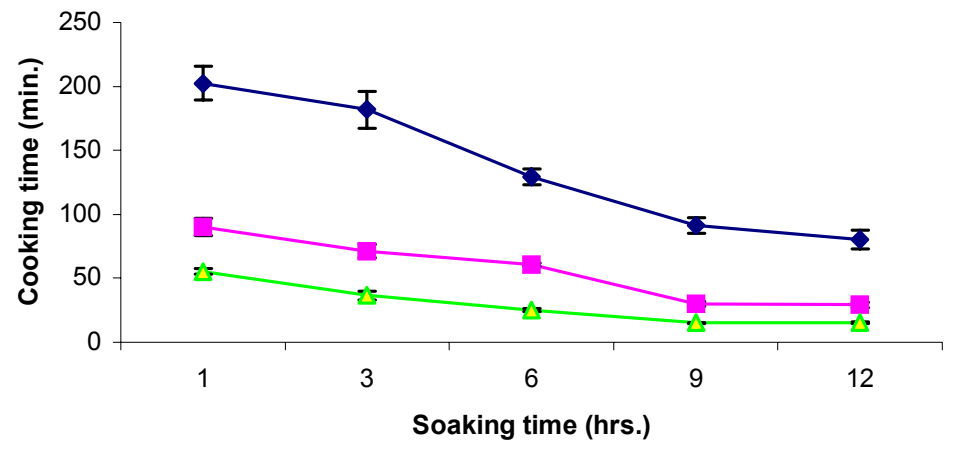

Figure 4 Cooking time of blanched grass pea seeds. Data represents \pm of S.E.M five independent tests 


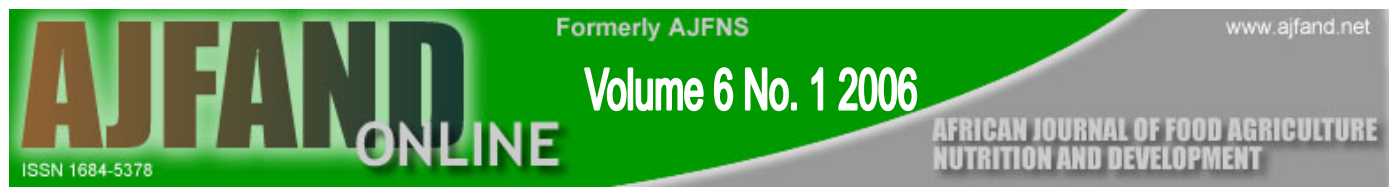

\section{DISCUSSION}

Water absorption values for unblanched seeds were equal during the first hour of soaking, which then varied according to both time of soaking and soaking solution. The unblanched seeds soaked in salt and wood ash solutions showed the highest rate of water absorption than seeds soaked in water. Water absorption is a measure of gross water uptake by seeds during soaking and is influenced by the integrity of the seed coat. Water uptake by seeds is driven by several forces at various tissue levels. The osmotic potential and matric potential contribute to the water potential of a system by the presence of dissolved solutes and hydrocolloids, respectively. Leached solids thus determine water uptake because of the decrease in the differential between intracellular and extra cellular water potentials [7].

Blanching had a marked effect on the water absorption values of the seeds. For blanched seeds, the first hour of soaking seemed to be central since a wide variation in the imbibed water was observed as compared to the unblanched seeds. The increase in water absorption of blanched seeds may be attributed to the change in the integrity of the seed coat due to heat treatment resulting in alteration of the anatomical barriers of the hilum allowing water to penetrate more rapidly. Varrian-Mariston and Jackson and Deshpande and Cheryan observed that the hilum and micropyle were the most important structural features influencing the initial water uptake of beans $[8,9]$.

Like water absorption, differences occurred in swelling power during the initial phase of soaking due to blanching when compared to unblanched seeds. The observed differences may be due to the effect of blanching on seed coat which increased the imbibition of water resulting in noticeable swelling of the structural cells and swelling power of seeds. In a similar study, it was reported that blanching markedly improved the swelling power of winged beans [10].

Leaching of solids during soaking of the unblanched seeds was lower compared to blanched seeds. The rate of loss of solids was approximately linear throughout the soaking period in both cases. However, leaching losses of solids during soaking of blanched and unblanched seeds in salt and or wood ash solutions were higher than those soaked in water. Such variation may be related to the breakdown of intercellular components, as well as to water taken up by the seeds because of the contribution of leached solids to the osmotic and matric potentials of the solutions to which they are leached. Although a higher level of leached solids in the present study may reduce nutrient contents such as vitamins, minerals and amino acids, it also reduces the level of anti-nutritional factors, particularly the neurotoxin $\beta$-ODAP and may be beneficial in preparing safe grass pea foods [11]. In a separate study, soaking and cooking treatments reduced the contents of anti-nutritional factors of grass pea and winged bean seeds [12, $13,14]$. In the present study, a significant positive correlation was observed between the time for soaking and swelling power, water absorption and leached solids [10]. 
The term 'cookability', as applied to legume seeds, refers to the condition by which they achieve the desired degree of tenderness during cooking and become acceptable to consumers. Cooking of blanched grass pea seeds to 'eating soft' increased the water absorption, swelling power and leached solids significantly, in agreement with some previous work on winged beans [9, 10, 14, 15]. Hydration is usually considered necessary to decrease cooking times and increase drained weight. In the case of blanched seeds soaked in salt solution for 12 hours and cooked to 'eating soft', the degree of hydration was slightly higher than those seeds soaked for a similar length of time in water and wood ash solutions, the variations were not, however, significant.

The time taken to cook legumes is affected by the permeability of seed coat and cotyledons to hot water. In the present study, the pretreatment of seeds, duration of soaking and type of soaking solution influenced the cooking time. A significant variation in cooking time is observed between blanched and unblanched seeds. The greater reduction in cooking time observed by pre-treatment of blanched seeds in salt and wood ash solutions could be explained by the fact that the presence of cations in the soaking medium increased the softening rate. Softening of pretreated seeds may be due to ion exchange and probably also by chelation of ions responsible for cellular firmness, resulting in solubilization of pectin substances which facilitated easier penetration and faster hydration of interior starch and protein molecules resulting in quick-cooking grass pea seeds $[16,17]$. There is evidence that after 9 hours of soaking blanched seeds in both salt and wood ash solutions, further hydration did not cause any appreciable reduction in cooking time, similar to the studies on dry legumes [18]. The present study results indicated that soaking blanched grass pea seeds in either salt or wood ash solution for 9 hours was preferable than soaking in water alone, because under such conditions 15 or 30 minutes were found to be adequate for cooking.

The type of pretreatment and soak solution also altered the sensory characteristics of cooked grass pea seeds. Blanched seeds pre-soaked in the three soaking solutions and cooked were slightly higher in general acceptability as compared to unblanched seeds pretreated with the three soaking solutions. Of the various sensory properties, tenderness score of cooked seeds pretreated in water was considerably lower than those in pre-treated salt or wood ash solution. In a similar study, treatment with baking soda or sodium bicarbonate has been reported to produce beans with higher sensory characteristics than those treated with other materials $[11,12,15]$.

\section{CONCLUSION}

The quick-cooking grass pea was produced by blanching the seeds in salt and wood ash solutions. Our data suggests that blanching and hydration of grass pea seeds improved the sensory characteristics of cooked seeds, significantly reduced the cooking time and increased the tenderness of the cooked seeds compared to unblanched seeds. Application of blanching preceded by soaking at village level as an integral part of traditional methods of processing grass pea seeds, thus offers the dual advantage of 


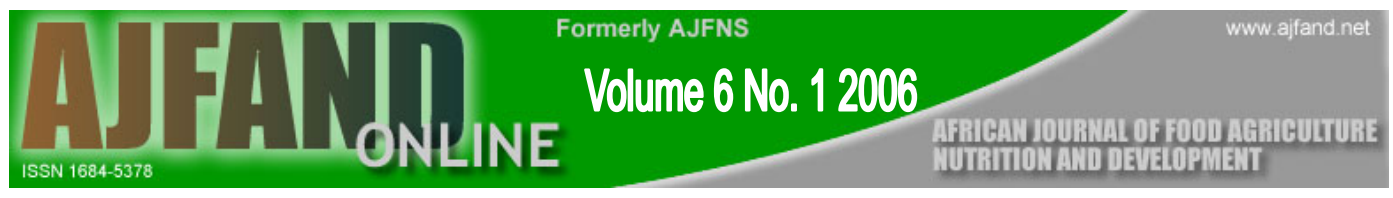

saving valuable fuels by shortening cooking time, as well as rendering the seeds more acceptable to consumers.

In addition, soaking blanched seeds prior to cooking is more appropriate than cooking for over three hours from the point of view of fuel consumption and texture. The grass pea treatments examined in this study can thus be used for food preparation at the village level. In absence of salt, wood ash suspension treatment may be a satisfactory alternative in the production of quick-cooking grass pea seeds.

\section{ACKNOWLEDGEMENT}

This study was sponsored by the Ethiopian Health and Nutrition Research Institute 


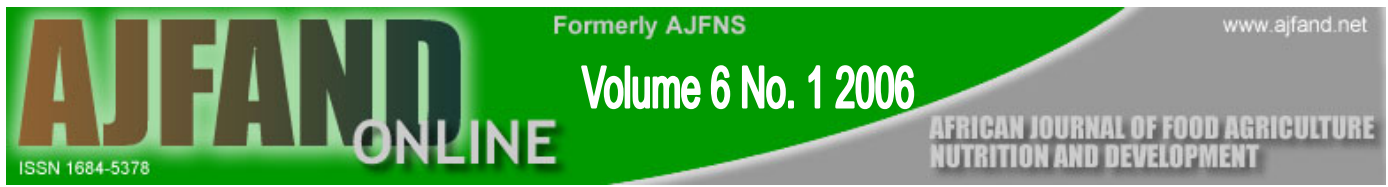

Table 1.Characteristics of soaked grass pea seeds without blanching

\section{Soaking time (hour)}

$\begin{array}{lllllll}\text { Parameter } & \begin{array}{l}\text { Soaking } \\ \text { solution }\end{array} & \mathbf{1} & \mathbf{3} & \mathbf{6} & \mathbf{9} & \mathbf{1 2} \\ \mathrm{LS}, \mathrm{g} \mathrm{kg}^{-1} & \text { Water } & 1.0 \pm 0.2 & 3.4 \pm 0.2 & 5.2 \pm 0.3 & 7.4 \pm 0.2 & 8.0 \pm 0.3 \\ & \text { Salt } & 3.8 \pm 0.2 & 5.6 \pm 0.2 & 11.8 \pm 0.4 & 15.6 \pm 0.3 & 20.0 \pm 0.3 \\ & \text { Wood ash } & 4.8 \pm 0.3 & 8.2 \pm 0.2 & 12.5 \pm 0.5 & 24.8 \pm 0.3 & 26.0 \pm 0.2 \\ \mathrm{SP}, \mathrm{g} \mathrm{kg}^{-1} & \text { Water } & 10.5 \pm 2.2 & 10.4 \pm 2.2 & 60.5 \pm 3.1 & 81.3 \pm 4.1 & 83.5 \pm 7.2 \\ & \text { Salt } & 38.4 \pm 3.1 & 99.5 \pm 7.3 & 150.6 \pm 9.3 & 160.6 \pm 5.2 & 182.3 \pm 4.2 \\ & \text { Wood ash } & 39.2 \pm 2.4 & 110.3 \pm 5.5 & 151.7 \pm 3.2 & 170.3 \pm 4.4 & 188.7 \pm 5.2 \\ & & & & & \end{array}$

Table 2. Soaking characteristics of blanched grass pea seeds ${ }^{a b}$

\begin{tabular}{|c|c|c|c|c|c|c|}
\hline \multicolumn{7}{|c|}{ Soaking time (hour) } \\
\hline Parameter & $\begin{array}{l}\text { Soaking } \\
\text { solution }\end{array}$ & 1 & 3 & 6 & 9 & 12 \\
\hline \multirow[t]{3}{*}{$\mathrm{LS}, \mathrm{g} \mathrm{kg}^{-1}$} & Water & $7.2 \pm 4.1$ & $13.1 \pm 1.3$ & $18.6 \pm 1.2$ & $21.8 \pm 1.1$ & $26.9 \pm 1.2$ \\
\hline & Salt & $30.6 \pm 3.1$ & $36.7 \pm 2.7$ & $40.8 \pm 1.1$ & $45 \pm 9 \pm 1.2$ & $49.0 \pm 1.5$ \\
\hline & Wood ash & $32.1 \pm 1.3$ & $35.1 \pm 1.3$ & $39.8 \pm 1.2$ & $44.1 \pm 2.7$ & $49.6 \pm 1.3$ \\
\hline \multirow[t]{3}{*}{$\mathrm{SP}, \mathrm{g} \mathrm{kg}^{-1}$} & Water & $142.1 \pm 3.3$ & $184.7 \pm 1.3$ & $306.6 \pm 6.2$ & $604.9 \pm 7.6$ & $618.2 \pm 4.3$ \\
\hline & Salt & $652.4 \pm 2.2$ & $653.2 \pm 1.4$ & $704.9 \pm 4.3$ & $842.5 \pm 5.2$ & $849.5 \pm 2.2$ \\
\hline & Wood ash & $562.5 \pm 3.3$ & $778.8 \pm 4.1$ & $781.7 \pm 1.8$ & $798.1 \pm 6.5$ & $801.7 \pm 2.3$ \\
\hline \multicolumn{7}{|c|}{${ }^{\mathrm{a}}$ Mean values \pm standard deviation. ${ }^{\mathrm{b}} \mathrm{LS}=$ leached solids, $\mathrm{SP}=$ swelling power. } \\
\hline \multicolumn{7}{|c|}{ 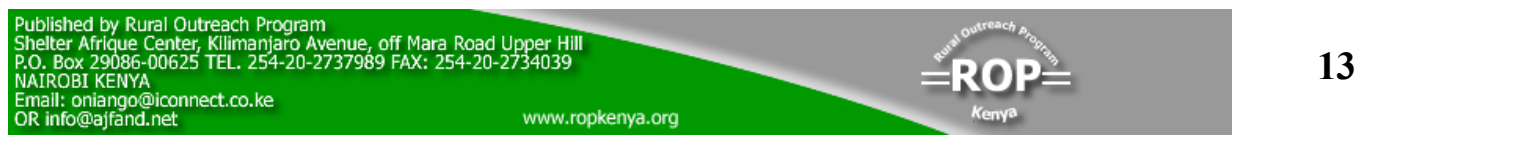 } \\
\hline
\end{tabular}




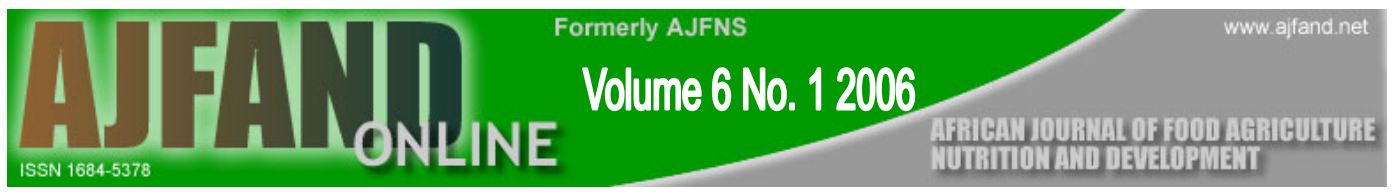

Table 3. Cooking characteristics of blanched then soaked grass pea seeds ${ }^{\mathrm{a} b}$

\begin{tabular}{|c|c|c|c|c|c|c|}
\hline \multirow[b]{2}{*}{ Parameter } & \multicolumn{5}{|c|}{ Soaking time (h) } & \multirow[b]{2}{*}{12} \\
\hline & $\begin{array}{l}\text { Soaking } \\
\text { solution }\end{array}$ & 1 & 3 & 6 & 9 & \\
\hline \multirow[t]{3}{*}{$W A, \mathrm{~kg}^{-1}$} & Water & $817.3 \pm 4.6$ & $820.7 \pm 2.2$ & $847.9 \pm 4.4$ & $880.3 \pm 6.1$ & $997.5 \pm 3.4$ \\
\hline & Salt & $981.1 \pm 7.5$ & $1023.9 \pm 23.5$ & $1040.5 \pm 36.6$ & $1056.4 \pm 41.3$ & $1065.8 \pm 39.3$ \\
\hline & Wood ash & $936.4 \pm 8.3$ & $948.3 \pm 2.4$ & $955.7 \pm 3.4$ & $971.9 \pm 3.1$ & $1030.7 \pm 25.4$ \\
\hline \multirow[t]{3}{*}{ LS, g kg-1 } & Water & $33.8 \pm 2.2$ & $33.8 \pm 1.6$ & $35.0 \pm 1.4$ & $36.8 \pm 1.1$ & $40.8 \pm 1.8$ \\
\hline & Salt & $57.3 \pm 1.9$ & $59.2 \pm 1.9$ & $65.2 \pm 3.1$ & $72.1 \pm 1.7$ & $74.4 \pm 1.2$ \\
\hline & Wood ash & $51.7 \pm 1.8$ & $58.3 \pm 1.8$ & $64.3 \pm 1.4$ & $70.2 \pm 2.1$ & $73.5 \pm 2.1$ \\
\hline \multirow[t]{3}{*}{$\mathrm{SP}, \mathrm{g} \mathrm{kg}^{-1}$} & Water & $849.7 \pm 13.3$ & $864.7 \pm 3.2$ & $878.1 \pm 7.7$ & $892.3 \pm 7.8$ & $949.2 \pm 2.1$ \\
\hline & Salt & $1104.9 \pm 12.5$ & $1109.4 \pm 7.9$ & $1196.8 \pm 35.4$ & $1223.7 \pm 23.2$ & $1250.6 \pm 18.2$ \\
\hline & Wood ash & $864.8 \pm 12.3$ & $875.8 \pm 12.7$ & $891.4 \pm 5.9$ & $980.8 \pm 17.1$ & $1019.5 \pm 18.4$ \\
\hline \multirow[t]{3}{*}{$\mathrm{DH}$} & Water & $1.6 \pm 10.1$ & $1.6 \pm 0.1$ & $1.8 \pm 0.1$ & $1.8 \pm 0.1$ & $1.9 \pm 0.2$ \\
\hline & Salt & $2.1 \pm 10.1$ & $2.2 \pm 0.1$ & $2.2 \pm 0.2$ & $2.1 \pm 0.1$ & $2.0 \pm 0.2$ \\
\hline & Wood ash & $1.9 \pm 0.1$ & $1.9 \pm 0.1$ & $2.0 \pm 0.1$ & $2.0 \pm 0.1$ & $2.0 \pm 0.1$ \\
\hline
\end{tabular}

a Mean values $\pm \mathrm{SD} .{ }^{\mathrm{b}} \mathrm{WA}=$ water absorption. $\mathrm{LS}=$ leached solids. $\mathrm{SP}=$ swelling power. $\mathrm{DH}=$ degree of hydration. 


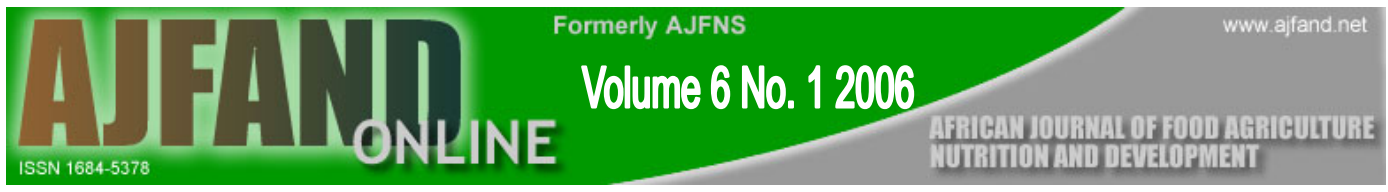

Table 4. Sensory properties of blanched, soaked then cooked grass pea seeds ${ }^{\mathrm{a} b}$

\begin{tabular}{|c|c|c|c|c|c|c|}
\hline \multirow[t]{2}{*}{ Parameter } & \multicolumn{3}{|c|}{$\begin{array}{l}\text { Unblanched seeds } \\
\text { Soaking solution }\end{array}$} & \multicolumn{3}{|c|}{$\begin{array}{l}\text { Blanched seeds } \\
\text { Soaking solution }\end{array}$} \\
\hline & Water & Salt & Wood ash & Water & Salt & Wood ash \\
\hline Color & $2.1 \pm 0.1$ & $2.4 \pm 0.2$ & $2.3 \pm 0.1$ & $2.8 \pm 0.3$ & $3.0 \pm 0.2$ & $2.7 \pm 0.2$ \\
\hline Mouth feel & $2.4 \pm 0.3$ & $2.6 \pm 0.1$ & $2.4 \pm 0.3$ & $3.0 \pm 0.1$ & $3.3 \pm 0.1$ & $3.4 \pm 0.2$ \\
\hline Flavor & $2.5 \pm 0.4$ & $2.6 \pm 0.3$ & $2.3 \pm 0.1$ & $3.6 \pm 0.2$ & $3.4 \pm 0.2$ & $3.2 \pm 0.1$ \\
\hline Taste & $2.3 \pm 0.2$ & $2.5 \pm 0.4$ & $2.1 \pm 0.2$ & $3.1 \pm 0.1$ & $2.9 \pm 0.2$ & $2.7 \pm 0.2$ \\
\hline Tenderness & $2.0 \pm 0.4$ & $2.8 \pm 0.3$ & $2.4 \pm 0.4$ & $2.9 \pm 0.3$ & $3.6 \pm 0.2$ & $3.8 \pm 0.1$ \\
\hline $\begin{array}{l}\text { General } \\
\text { acceptability }\end{array}$ & $2.4 \pm 0.1$ & $2.7 \pm 0.2$ & $2.1 \pm 0.5$ & $3.3 \pm 0.2$ & $3.4 \pm 0.1$ & $3.3 \pm 0.2$ \\
\hline
\end{tabular}




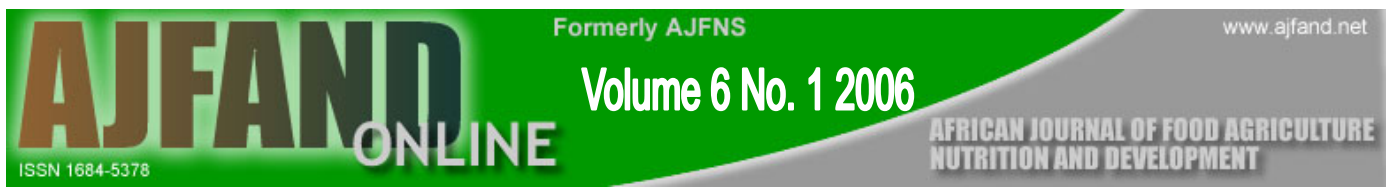

\section{REFERENCES}

1. Campbell CG, Mehra PB, Agarwal YZ, Chen AM, El-Ali A, Khwaja HIT, Yadav CR, Joy J, and WA Araya Current status and future strategy in breeding grass pea (Lathyrus sativus ).Euphatica 1994;73:167-175

2. Dibabe A, Wolde WA, Hundie B, Ensermu R, Haile W and Y Ashagrie The status of grass pea (Lathyrus sativus) research and production in Ethiopia. In: Abegaz B, Tekle Haimanot R, Palmer VS and PS Spencer (eds.). Nutrition, Neurotoxin and Lathyrism: The ODAP Challenge. Third World Medical Research Foundation, New York.1994; 44-60.

3. Teklehaimanot R, Wuhib E, Kassina A, Kidane Y, Alemu T and PS Spencer Patterns of Lathyrus sativus (grass pea) consumption and ODAP content of food samples in the lathyrism endemic regions of North West Ethiopia. Nutr. Res. 1993;3:1113-1126.

4. Urga K and Mengistu M Gebretsadik Development of quick-cooking grass pea seeds. Ethiop. Health Nutr.Res.Newslet. 1997; 1(6):4-8.

5. Plhak LC, Caldwell KB and DW Stanley Comparison of methods used to characterize water imbibition in hard-to-cook beans. J Food Sci. 1989; 54: 326336.

6. Narasimha HV and HSR Desikachar Objective methods for studying of Tur pulse and factors affecting varietal differences in cooking. J. Food Technol. 1978; 15: $149-152$.

7. Hiks MJ, McCannel A and DW Stanley Hard-to-cook defect in black beans. Soaking and cooking process J. Food Chem.1987; 35:576-583.

8. Varriano-Marston EV and CM Jackson Hard to-cook phenomena; structural changes during storage and imbibition. J Food Sci. 1980; 46: 1379-1385.

9. Deshpande DG and M Cheryan Microstructure and water up take of phaseolus and winged beans. J Food Sci. 1986; 51:1218-1223.

10. King RD and $\mathbf{P}$ Puwstein Effect of blanching and soaking on winged beans (Psophocarpus tetragnolobus LDC). J. Sci. Food Agric. 1984; 35: 441-446.

11. Urga $\mathbf{K}$ and $\mathbf{M}$ Gebretsadik The effect of soaking time and soaking solution on the nutritional quality of grass pea seeds. Ethiop. J. Health Dev.1993; 7:79-83

12. Kebede B, Urga $\mathbf{K}$ and A Nigatu Effect of processing on trypsin inhibitors, tannins, phytic acid and $\beta$-ODAP contents of grass pea seeds. Ethiop. J. Health Develop. 1995; 9:97-103. 
13. Kialasapathy K, Perera PAL and JH MacNeil Soaking studies in winged beans to process full fat flour and determine its shelf-life stability. J. Food Sci. 1985; 50: 773-776.

14. Ekpenyoung TE and RL Brochers Effect of cooking on the composition of winged beans. J. Food Sci. 1980; 45: 1559-1560.

15. Sambudi $H$ and KA Buckle Characteristics of winged bean sees during soaking and boiling. J. Sci. Food Agric. 1991; 57: 585-595.

16. Silva C, Bates RP and JC Deng Influence of soaking and cooking upon its softening and quality of black beans (Phaseolus vulgaris L). J. Food Sci. 1981; 46: $1716-1720$.

17. Varrian-Mariston E and E Omana Effects of sodium salts solution on the chemical composition and morphology of black beans (Phaseolus vulgaris).J. Food Sci. 1979; 44:531-536.

18. Buckle KA and H Sambudi Effect of soaking and boiling treatments on the quality of winged bean seed. J.Sci.Food Agric. 1990; 53:379-399 